Vol. 44, N. 4 : pp. 395 - 399, December, 2001 ISSN 1516-8913 Printed in Brazil

\title{
Seasonal Variation in the Abundance of Seabirds in Areas of Mariculture
}

\author{
Joaquim Olinto Branco ${ }^{1}$; Jan Raphael Reuter Braun ${ }^{1}$ and José Roberto Verani ${ }^{2}$ \\ ${ }^{1}$ Centro de Ciências Tecnológicas, da Terra e do Mar - CTTMar, Universidade do Vale do Itajaí. Caixa Postal 360, \\ 88301-970 Itajaí - SC, Brasil; ${ }^{2}$ - Universidade Federal de São Carlos. Cx. Postal 676, 13565-905 São Carlos - SP, \\ Brazil
}

\begin{abstract}
Mariculture has emerged as a complementary income for small fishermen along the coast of the state of Santa Catarina, Brazil, causing significant alterations in the coastal landscape and creating a new substratum seabirds. From March 1998 to February 1999, 48 censuses were carried out at four sample times, registering an average annual occurrence of 4448.7 birds, distributed among five seabird species. Laridae dominated in diversity and abundance, contributing with $98.1 \%$ of the birds recorded. The number of birds per float varied depending on the time of day and season of the year, showing an average of 2.09/1. Seabirds use the mariculture area as a place to rest, to clean their feathers and to overnight.
\end{abstract}

Key words: Seabirds, area of mariculture, Itapocoroy inlet

\section{INTRODUCTION}

The activity of mariculture has emerged to complement the income of small fishermen along the coast of the state of Santa Catarina, Brazil. Today, eleven municipalities extending from Palhoça to São Francisco do Sul support the mariculture of shellfish and oysters. The municipality of Penha, SC, with its 94 registered producers, uses approximately 10000 floats in an area of $210000 \mathrm{~m}^{2}$, with a production of 1500 tons of mussels (Perna perna) in 1997/98, ranking at third place in the state's shellfish production. This activity has resulted in significant modifications of the coastal landscape, creating a new substratum for seabirds. After the fishermen come in or when ichthyofauna is discarded by the local shrimping fleet, most of the Tern, Kelp Gulls and Cormorant use the mariculture floats as a substratum to rest and clean their feathers (Branco, 1998). Owing to the lack of information regarding the use of these areas of mariculture by seabirds, this study aims to supply data to monitor birds in areas of mariculture along the coast of Santa Catarina, Brazil.

\section{MATERIAL AND METHODS}

Monthly censuses of seabirds were carried out from March 98 to February 99 in the area of mariculture of the Itapocoroy inlet in Penha, Sta. Catarina. Four censuses were made each month with three-hour intervals between each observation, starting at 8:00 a.m. Sporadic nocturnal observations were also made to determine which birds overnighted in the area. The birds observed on the floats were identified according to Sick (1997). The number and activity developed by the birds on the floats were recorded at each census, using 10x50 binoculars. The floats 
consist of 60-liter plastic barrels wrapped in nylon nets and tied to long nylon lines, placed at 2-meter intervals from each other in straight lines extending to about $100 \mathrm{~m}$, with 5 to 10 -meter spacing between lines. The long lines were held at the bottom by weights or anchors (Figure 1). A flat-bottomed boat with a $25 \mathrm{hp}$ outborad motor was used to navigate between the long lines. Three counts were made (May, Oct 98 and Feb 99) to determine the substratum available for the seabirds, obtaining the relation between the number of birds per float. Concurrently to the censuses, a record was kept of the number of fishing boats acting in the area from 8 a.m. to 5 p.m. Based on the censuses, the species were grouped in three categories, i.e., regular (9 to 12 months), seasonal (6 to 8 months) and occasional ( 1 to 5 months). ANOVA ( $p<0.01$ ) was used to compare the abundance of birds between the months and times of the censuses (Sokal and Rohlf, 1969).

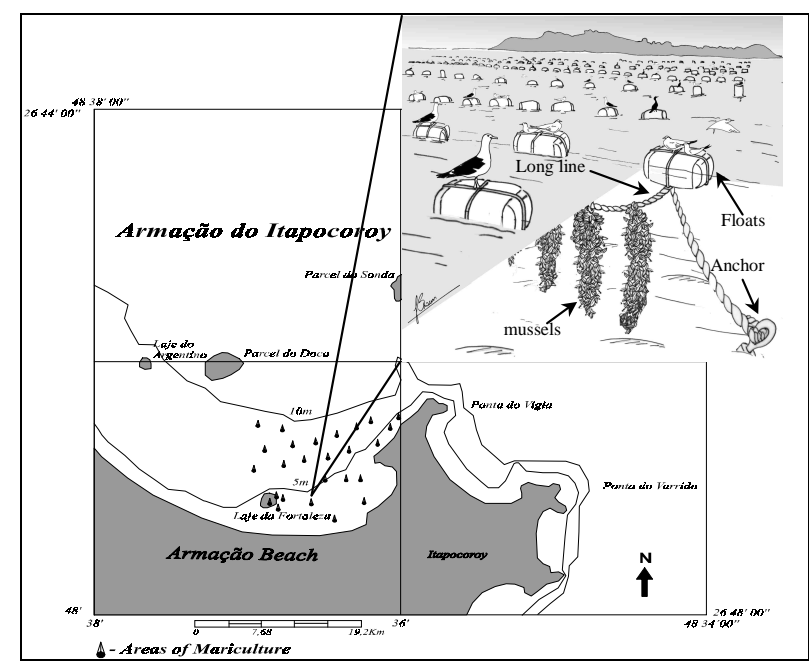

Figure 1 - Studied area and mariculture scheme.

\section{RESULTS AND DISCUSSION}

Occurrence of seabirds: From March 98 to February 99, 48 censuses were carried out at four different sampling times, registering an average annual occurrence of 4448.7 specimens distributed among two families and five species of seabirds (Table 1). In general, the abundance was observed to increase gradually from 8 a.m. on, reaching a peak at 5 p.m. With the exception of the Olivaceus Cornorant Phalacrocorax brasilianus (Gmelim,1789), all the Laridae showed a regular occurrence in the censuses (Table 1). Studies involving seabirds on the coast of Santa Catarina are restricted mainly to the work of Bege and Pauli (1988), Schiefler and Soares (1994) And Soares and Schiefler (1995). According to these authors, the Laridae present the greatest diversity and abundance in sampling, which was confirmed in the mariculture area.

Laridae contributed with $98.1 \%$ of the recorded specimens, with Cayenne Tern Sterna eurygnatha (Sainders,1876) representing 62.5\% and the Kelp Gull Larus dominicanus (Lichtenstein, 1823) $31.8 \%$; the other three species together contributed with $5.7 \%$ of the specimens recorded (Figure 2).

Seasonal variation in the abundance: The analysis shown in Figure 3 indicated seasonal oscillations in the abundances of seabirds during the day in the area of mariculture. The greatest average abundance, regardless of the time of day, were registered between February and April. Moderate increments were observed between 8 and 11 a.m. in November and June (Figures 3a, $3 \mathrm{~b}$ ) and between 2 p.m. and 5 p.m. in August and October (Figures 3c, 3d). The lowest number of seabirds were found to occur in December, May and September (Figure 3). ANOVA $p<0.01$ $(\mathrm{F}=7.896$; gl 3-12) showed significant differences between the abundance of birds and the seasons of the year. A comparison of the averages indicated that these differences were related to the greatest abundances recorded during summer. This tendency is illustrated in Figure 4, which shows that starting from the winter months, there was a gradual increase in the number of birds until the highest average frequencies were reached in summer. The variations in the abundance of seabirds in the study area are probably related to life cycle events. Thus, the recruitment of juveniles and the return of adult Sterna eurygnatha to the mariculture area occurred from March to April. Starting in May, part of the population gradually disperses to new feeding areas (Branco, 1998). 
Table 1 - List of birds species and their respective annual occurrence, by time of census. Occurrence (Occ.) is classified into regular $(>)$, seasonal $(+)$ and occasional $(<)$.

\begin{tabular}{lcccccc}
\hline \multicolumn{1}{c}{ Family / Species } & $8 \mathrm{am}$ & $11 \mathrm{am}$ & $2 \mathrm{pm}$ & $5 \mathrm{pm}$ & Total & Occ. \\
\hline Laridae & & & & & & \\
Larus dominicanus (Lichtenstein, 1823) & 911 & 1035 & 1651 & 2057 & 5654 & $>$ \\
Sterna eurygnatha (Sainders, 1876) & 2170 & 2497 & 3161 & 3303 & 11131 & $>$ \\
Sterna hirundinacea (Lesson, 1831) & 73 & 99 & 178 & 255 & 605 & $>$ \\
Sterna maxima (Boddaert, 1783) & 18 & 17 & 9 & 25 & 69 & + \\
Phalacrocoracidae & & & & & & \\
Phalacrocorax brasilianus (Gmelin, 1789) & 70 & 82 & 118 & 66 & 336 & $>$ \\
Total & 3242 & 3730 & 5117 & 5706 & 17795 & \\
\hline
\end{tabular}

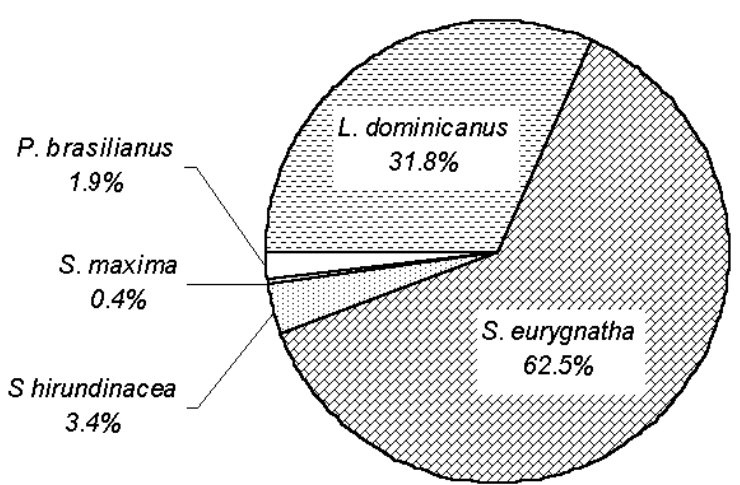

Figure 2 - Relative occurrence of the seabird species in the mariculture area.

It was observed that in April and May, the adult Larus dominicanus move to coastal islands, where they reproduce from June to October (Bege and Pauli, 1988; Soares and Schiefler, 1995). Although ANOVA $\mathrm{p}<0.05(\mathrm{~F}=1.163 ; \mathrm{gl} 3-12)$ failed to indicate a significant difference between the abundance of seabirds and the times of the day when the censuses were made, the analysis in Figure 5 shows the progressive arrival of birds to the mariculture area from 8 a.m. to 5 p.m. This increase in the number of seabirds was inversely proportional to the number of fishing boats in operation (Figure 6). Fishing for Sea-bob shrimp in the Itapocoroy inlet was dubbed "fishing from sun to sun", i.e., beginning at sunrise and ending just before sunset (Branco et al., 1998), with the greatest fishing activity concentrated during the morning hours, when a significant contingent of seabirds fed on the discarded ichthyofauna, thus keeping the numbers in the mariculture area relatively low. The number then increased with the gradual return of the fishing boats to their moorage, reaching its highest frequency at 5 p.m. (Figures 5, 6).

Number of seabirds per float : Occupation of the floats varied depending on the time of day and season of the year. In general, each float was occupied by two birds (2.09/1); the Cayenne Tern Sterna eurygnatha presented the highest rate of occupation (1.33/1), followed by $L$. dominicanus (0.66/1), S. hirundinacea (0.07/1), P. brasilianus $(0.03 / 1)$ and $S$. maxima (0.008/1) (Table 2). The mariculture activity (Perna perna), has caused significant alterations in the coastal landscape of Itapocoroy inlet, Penha, with the increasing number of floats used in the support of long line. According to the fishermen of the region, the seabirds were frequently seen at the beaches and costal areas. Nowadays, the birds rest specially on the floats, wich represent a shelter from predator and are less disturbed by humans. The high seabird excrement apport along the year suggested a contribution to the primary production of the mariculture area. However, the excrements of some seabirds, like Larus dominicanus, might contain pathogenic or parasitic agents to the human beings that consume mussels in natura. 


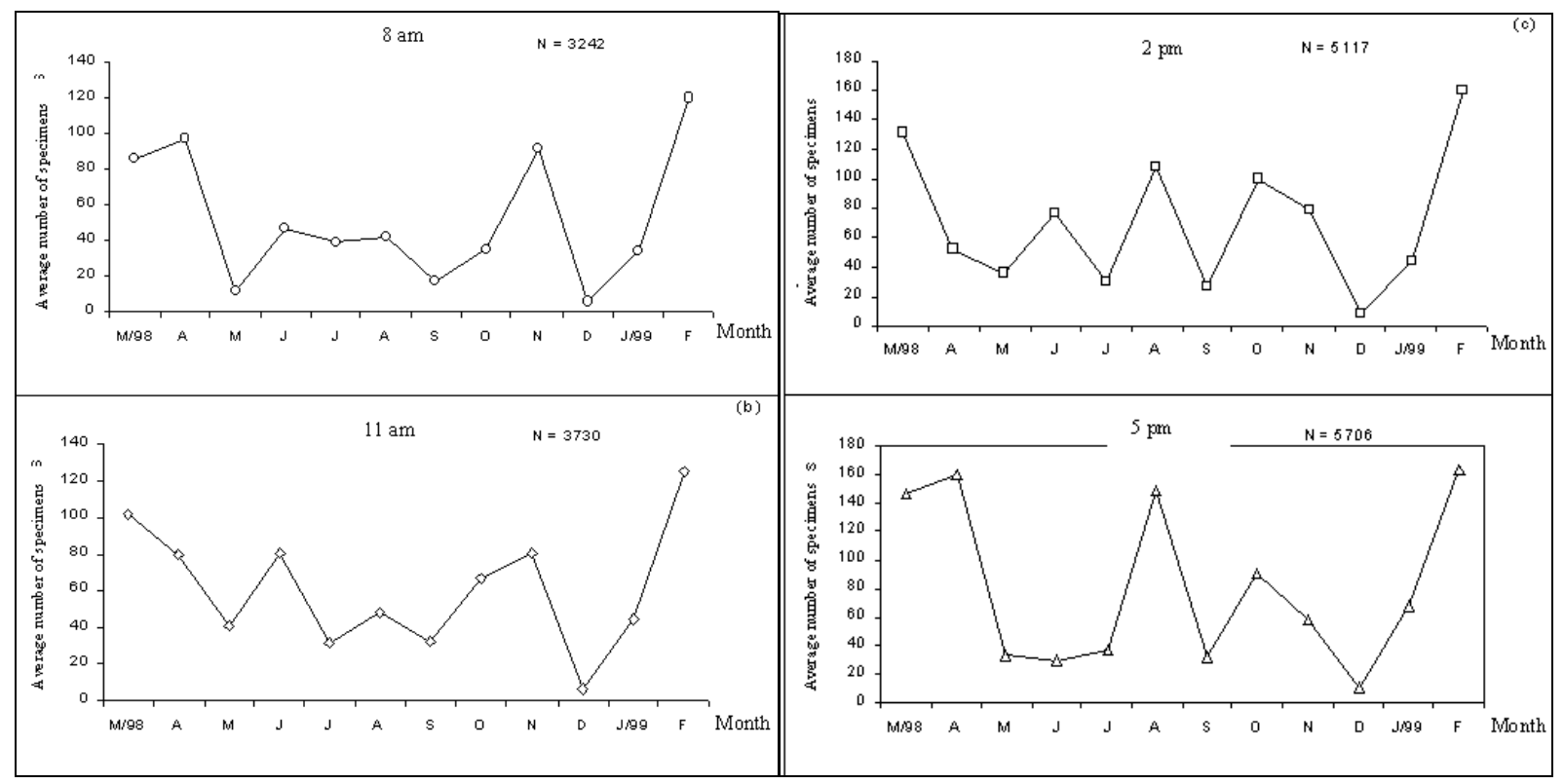

Figure 3 - Average monthly abundance of seabirds by time of census in the mariculture area.

Table 2 - Relation between the number of seabirds and of floats (available substratum) in three counts in the mariculture area.

\begin{tabular}{lcccc}
\hline & May 98 & Oct 98 & Feb 99 & Annual Proportion* \\
\cline { 2 - 5 } Species/Floats & $\mathrm{n}=8193$ & $\mathrm{n}=8301$ & $\mathrm{n}=8499$ & $\mathrm{n}=8499$ \\
\hline L. dominicanus & $0.042 / 1$ & $0.027 / 1$ & $0.239 / 1$ & $0.669 / 1$ \\
S. eurygnatha & $0.040 / 1$ & $0.144 / 1$ & $0.147 / 1$ & $1.336 / 1$ \\
S. hirundinacea & $0.001 / 1$ & $0.018 / 1$ & $0.008 / 1$ & $0.071 / 1$ \\
S. maxima & $0.001 / 1$ & - & $0.001 / 1$ & $0.008 / 1$ \\
$P$. brasilianus & - & $0.01 / 1$ & $0.006 / 1$ & $0.039 / 1$ \\
\hline Proportion & $0.085 / 1$ & $0.206 / 1$ & $0.402 / 1$ & $2.093 / 1$ \\
\hline
\end{tabular}

*= Calculation of the annual proportion was based on the data of February 1999.

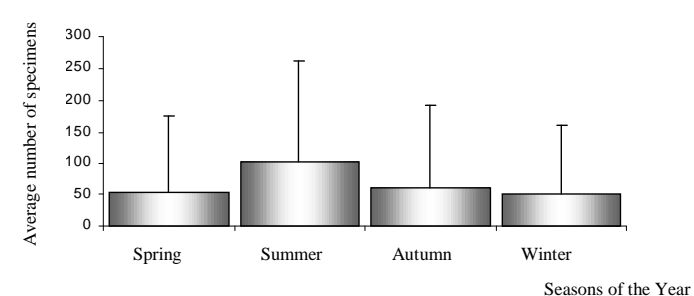

Figure 4 - Average seasonal abundance of seabirds in the mariculture area. Cylinder $=$ mean; Line $=$ standard deviation.

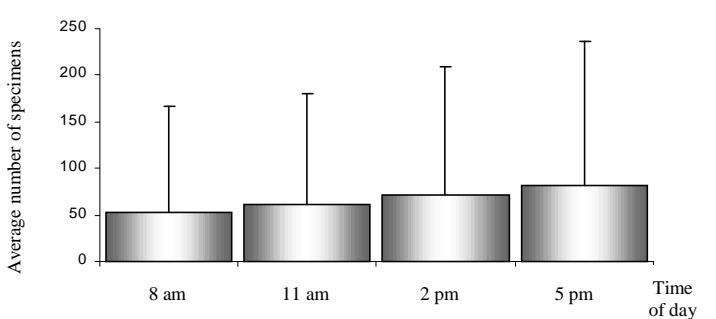

Figure 5 - Average abundance of seabirds per time of census in the mariculture area. Cylinder $=$ mean; Line $=$ standard deviation. 


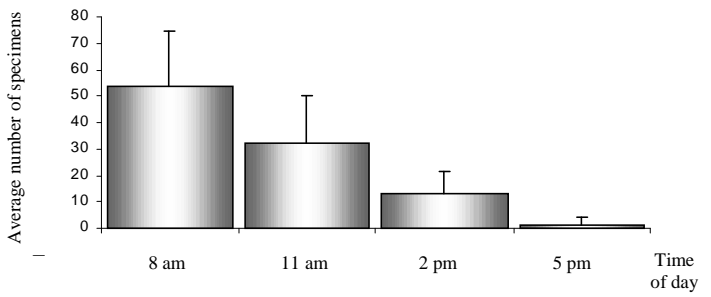

Figure 6 - Average number of boats from the fleet of small fishermen fishing for Sea-bob shrimp between 8 a.m. and 5 p.m. during the period studied. Cylinder $=$ mean; Line $=$ standard deviation .

The new substratum formed by the floats, in spite of being considered an anthropogenic factor, has contributed to the increasing in the abundance of the seabirds because it represents a safe place to rest, eat, clean the feathers and overnight. As of 1994, the introduction of the floats, which are used to hold up the marine culturists' long lines, provided the seabirds of the Itapocoroy inlet with a new substratum that proved suitable for resting and preening (Branco, 1998). After they finish fishing or feeding off the ichthyofauna that is caught with the Sea-bob shrimp and discarded, most of the birds occupy the mariculture area. Our observations indicated that they were generally taking care of themselves between 11 a.m. and 2 p.m., when a large numbers of them had already returned from fishing and rested from 2 p.m. to 5 p.m. In the late afternoon, $P$. brasilianus moved to the continent, while Laridae went back to foraging close to the mariculture area. After 6 p.m. or 8 p.m., depending on the season, kelp gulls and tern group together in mixed flocks on the floats to overnight in the mariculture area.

\section{ACKNOWLEDGEMENTS}

The authors thank the Dean's Office of the Research and Post-Graduate of UNIVALI for the Introduction to Science scholarship granted to J.R.R.B., the Professors of the CTTMar (Campus V) for the facilities placed at their disposal, the trainees of the Laboratory of Biological Oceanography (Zoology) and the students of Zoology II of the Oceanography course of CTTMar - UNIVALI for their valuable contribution to the field work.

\section{RESUMO}

A atividade de Maricultura surgiu como um complemento de renda para os pescadores artesanais do litoral de Santa Catarina, causando alterações significativas na paisagem costeira e criando um novo substrato para as aves marinhas. Durante o período de março/98 a fevereiro/99 foram realizados 48 censos entre os quatros horários de amostragens, registrando-se a ocorrência média anual de 4448.7 exemplares, distribuídos em cinco espécies de aves marinhas. Os Laridae dominaram em diversidade e abundância, contribuindo com $98.1 \%$ das aves registradas. O número de aves por flutuador variou em função do horário e época do ano, sendo em média de 2.09/1. As aves marinhas utilizam a área de maricultura como local de repouso, manutenção das penas e pernoite.

\section{REFERENCES}

Bege, L. A. R. and Pauli, B. T. (1988), As aves nas Ilhas Moleques do Sul - Santa Catarina: Aspectos da ecologia, etologia e anilhamento de aves marinhas. Florianópolis. FATMA, 64p.

Branco, J. O. (1998), Aves marinhas em áreas de maricultura: ocorrência e abundância. Anais do IV Simpósio de Ecossistemas Brasileiros. ACIESP, 104(3), 194-199.

Branco, J. O; Lunardon-Branco, M. J; Peret, A. C; Souto, F. X; Schveitzer, R. and Vale, W. G. (1998), Associação entre macroinvertebrados e peixes demersais na Armação do Itapocoroy, Penha, SC, Brasil. Brazilian Archives of Biology and Tecnolology, 41(2), 268-277.

Sick, H. (1997), Ornitologia Brasileira, edição revista e ampliada por José Fernando Pacheco. Rio de Janeiro: Editora Nova Fronteira. 912p.

Soares, M. and Schiefler, A. F. (1995), Aves da Ilhota da Galheta, Laguna, SC, Brasil. Arquivos de Biologia e Tecnologia, 38(4), 1101-1107.

Sokal, R. R. and Rohlf, F. J. (1969), Biometry, the principles and practies of statistics in biological research. W.H. Freeman and Co., San Francisco. $776 \mathrm{p}$.

Schiefler, A. F. and Soares, M. (1994), Estudo comparativo da avifauna das praias de Navegantes e Laguna, Santa Catarina. Biotemas, 7(1,2), 31-45.

Received: September 06, 2000; Revised: October 26, 2000; Accepted: April 26, 2001. 